\title{
O EGITO MÍTICO DE ATHANASIUS KIRCHER: O OBELISCUS PAMPHILIUS E A FONTE DOS QUATRO RIOS NA PRAÇA NAVONA
}

\author{
Evelyne Azevedo
}

A presente comunicação é fruto, fundamentalmente, do projeto de mestrado iniciado neste ano na UNICAMP. Intitulado "O Egito Mítico de Athanasius Kircher: o Obeliscus Pamphilius e a Fonte dos Quatro Rios na Praça Navona", o projeto tem como objetivo estudar a relação entre ambas as obras, a partir da análise do texto e do pensamento do jesuíta alemão Athanasius Kircher, propondo desta forma uma nova interpretação do monumento berniniano à luz das informações trazidas pelo texto.

A conquista do Egito pelos árabes, no século VII, reconquistou para o Oriente o Egito que o Helenismo e o Cristianismo conquistaram para o Ocidente. Tanto a Grécia quanto o Egito sucumbiram aos árabes, assim como o Cristianismo ao Islamismo. O Egito tornou-se apenas uma parte do Império Árabe, perdendo sua importância cultural junto ao Ocidente e sobrevivendo apenas na memória ocidental nas narrativas bíblicas.

Somente no século XIV, com os estudos sobre a literatura e a língua grega dos primeiros Humanistas, é que o Egito é redescoberto. A partir da leitura de importantes pensadores gregos, como Sólon, Pitágoras e Platão, os Humanistas descobriram uma cultura passível de ser comparada com a sua própria. Mais ainda: eles descobriram uma "cosmologia filosófica e a concepção de problemas religiosos fundamentais que estavam intrinsicamente relacionados às suas próprias idéias neoplatônicas, além de todo um pensamento místico consoante com suas próprias especulações"1. O Egito foi considerado assim fonte de conhecimento, na qual até mesmo os gregos se inspiraram.

Desse pensamento surgiu um crescente interesse pelas coisas egípcias e o mito de um Egito idealizado, origem de todo conhecimento místico e de toda verdade oculta. Toma forma assim a Hipótese Egípcia, que se tratava da idéia humanista da unidade humana e que procurava

\footnotetext{
${ }^{1}$ IVERSEN, Erik. Hieroglyphic studies of the Renaisssance, p. 15.
} 
demonstrar que era possível retornar à unidade original do pensamento humano: da religião, à mitologia e à linguagem² .

Tidos como principais manifestações da cultura egípcia, as pirâmides, obeliscos e os hieróglifos adquiriram posição de destaque nos estudos que se seguiram. Em especial estes últimos que, imitando a natureza, eram interpretados como uma manifestação simbólica da razão invisível, uma vez que os animais, as plantas e os outros elementos naturais são a maneira como Deus se expressa. Ao escrevê-los, o sacerdote estaria apenas copiando aquilo que já estava escrito no grande livro da natureza. Eram assim expressões da verdade divina ${ }^{3}$.

Contudo, a compreensão de seu verdadeiro significado não poderia ser obtida pela simples apreciação estética ou interpretação intelectual, mas somente poderia ser revelada aos iniciados pela experiência mística, baseada na inspiração divina. Assim, toda verdadeira experiência artística seria necessariamente uma revelação divina. ${ }^{4}$ Para os Humanistas, descobrir o significado dos hieróglifos era desvendar os segredos de uma linguagem universal cujos símbolos seriam capazes de expressar qualquer idéia, fosse ela metafísica ou não e, sobretudo, capazes de ser universalmente entendidos - desde que se fosse iniciado.

As traduções das inscrições hieroglíficas tornaram-se, na realidade, projeções alegóricas da teoria filosófica da cultura neoplatônica. Traduzidos de modo arbitrário e não através de uma regra sintática, as inscrições acabaram por exprimir aquilo que melhor conviesse ao intérprete ${ }^{5}$. Kircher insere-se nesta longa caminhada de decifração dos hieróglifos.

Situado na ponta da tradição humanista e célebre colecionista, o jesuíta alemão era um estudioso não só do mundo antigo, mas também do Oriente moderno. Um homem que procurava deter um saber global e possuía uma posição idônea para atuar no interior da cultura oficial com ampla disponibilidade de recursos econômicos para financiar suas pesquisas e suas publicações ${ }^{6}$.

\footnotetext{
2 RIVOSECCHI, Valerio. Esotismo in Roma Barocca: studi sul padre Kircher.Roma: Bulzoni Editore, 1982, p. 26.

${ }^{3}$ Idem, p. 60.

${ }^{4}$ IVERSEN, Erik, , p. 16.

${ }^{5}$ RIVOSECCHI, Valerio. Esotismo in Roma Barocca: studi sul padre Kircher.Roma: Bulzoni Editore, 1982, p. 51.

${ }^{6}$ FINDLEN, Paula (ed.). Athanasius Kircher: the last man who knew everything. Nova Iorque: Routledge, 2004, p. 53.
} 
Athanasius Kircher chegou a Roma no ano de 1635 para ocupar a cadeira de matemática no Colégio Romano da Ordem Jesuíta. Nesse momento, Roma dominava cultural e intelectualmente a Europa. Recomendado pelo Cardeal Francesco Barberini, sobrinho do Papa Urbano VIII, ele foi designado por este para chefiar uma comissão de interpretação dos hieróglifos. Sua primeira publicação nesse sentido, dedicada a Francesco Barberini, o Prodromus Coptus de 1636, apresenta uma pequena introdução ao Copta - língua litúrgica dos egípcios cristãos que mistura o egípcio ao grego - e fornece parcialmente uma gramática introdutória traduzida para o Latim.

Seus estudos o levaram a publicar ainda outros quatro livros sobre o tema, dentre eles o Obeliscus Pamphilius de 1650. Dedicado ao Papa Pamphili - Inocêncio X - por ocasião do Jubileu proclamado por ele neste ano. O livro comemorava a restauração e a colocação do obelisco egípcio na Praça Navona que seria utilizado por Bernini em sua Fonte dos Quatro Rios. A contra-capa do livro representa o Tempo derrubando o Obelisco e a Fortuna acorrentada a um bloco de pedra, mas Hermes ensina à Sabedoria os segredos dos hieróglifos. Esta última revela ao mundo o mistério ensinado por Hermes, por meio do livro de Athanasius Kircher, que ela está segurando.

A obra de Kircher marcou decisivamente sua geração sendo o primeiro estudo de peso da língua egípcia. E, apesar de seu trabalho ser pouco significativo em tentar decifrar os hieróglifos, Champollion afirmará posteriormente que seu estudo do copta foi de grande importância para que ele chegasse a decifração dos hieróglifos. Kircher acreditava que os hieróglifos não funcionavam exatamente como escrita, mas sim como representações simbólicas da teosofia expressa através de sinais universalmente inteligíveis. Neste livro, Kircher começa datando o obelisco que ele acredita ser de 1366 a. C. Em seguida, ele traduz os hieróglifos do obelisco, afirmando que as inscrições são adorações ao sol e que ele foi dedicado a sua divindade favorita: Hemephta. Ele ainda descreve todos os obeliscos de Roma, data-os e fornece suas procedências, como foram transportados e erigidos.

De acordo com ele, os hieróglifos que cobrem esses obeliscos foram inventados por Hermes Trimegistus - o deus Thoth, que em um dos mitos cosmogônicos egípcios cria a humanidade por meio da palavra - que teria vivido depois da Inundação e ensinado ao primeiro sacerdote seu significado. $\mathrm{O}$ culto aos deuses baseado nas doutrinas religiosas ensinadas 
por Noé declinaram dando origem ao mitos egípcios, como o de Osíris, por exemplo.

Contudo, a ascensão de Inocêncio X marcava uma mudança no cenário romano, que sofre um declínio na cena política européia. Principalmente, após o Tratado de Westphalia, em 1648, em que o enviado do Papa - Fabio Chigi - não é convidado a assinar o tratado que encerrou a Guerra dos Trinta Anos. "Pela primeira vez na Europa a paz foi feita sem a intervenção papal." 7

Fazia-se necessário, portanto, reafirmar o poder papal e a amplitude do catolicismo no mundo. É em meio a esse contexto que o Papa Inocêncio X encomenda a fonte da Praça Navona - que deveria simbolizar os quatro maiores rios da Terra e sobre a qual deveria haver um obelisco egípcio - primeiro a Borromini e depois a Bernini, com o claro interesse de representar a soberania católica sobre o paganismo e o mundo ultramarino.

Desde cedo Gian Lorenzo Bernini prestou serviço à Igreja, vinculando-se ao Papa Urbano VIII. Em 1625, passou ao cargo de supervisor das fontes da Praça Navona, em que trabalharia posteriormente. Apesar do pouco apreço de Inocêncio X pelo artista, o monumento proposto por Bernini era o que melhor representava os interesses papais, suplantando o projeto de Borromini.

Executada entre os anos 1648 e 1651, a Fonte dos Quatro Rios deveria marcar um novo ponto de fornecimento de água no centro da elipse formada pelo antigo circo de Domiciano e a presença da família Pamphili na Praça Navona. Freqüentemente considerada como a máxima expressão da fonte barroca romana, o monumento berniniano propõe a compenetração entre água e rocha; elementos escultóreos e arquitetônicos; figuras mitológicas, alegóricas e cristãs.

Composta de três partes, sua base se caracteriza por uma "montanha" rochosa de onde emergem as águas dos quatro maiores rios do mundo então conhecido: Ganges, Danúbio, Nilo e Rio da Prata. Outra possível interpretação para os rios é que eles simbolizassem os rios do Paraíso. É interessante notar que Kircher acreditava que sob as montanhas havia vastos reservatórios de água tal como ele os descreve em sua obra Mundus subterraneus.

\footnotetext{
${ }^{7}$ Idem, p. 53.
} 
Cada um dos rios é representado por um dos quatro colossos, cada um associado ainda a elementos da flora e da fauna alusivos a sua respectiva zona geográfica. O Rio Ganges é representado segurando um remo aludindo a navegabilidade de suas águas. O Danúbio é velho assim como o velho continente. O Nilo é representado por sua vez, com a cabeça coberta aludindo possivelmente ao pouco conhecimento da nascente de suas águas, descoberta somente em 1618 ou mesmo enfatizando o mistério do antigo conhecimento egípcio. Já o Rio da Prata é representado por um mouro com uma bolsa de moedas que se esparramam, fazendo referência às riquezas do Novo Mundo e com um dos braços levantados, representando possivelmente a iluminação da revelação apostólica. ${ }^{8}$

Sobre o conjunto, situa-se o obelisco egípcio que por sua vez é encimado não pela tradicional cruz, mas por uma pomba carregando no bico um ramo de oliveira. Emblema da família Pamphili e ao mesmo tempo do Espírito Santo, a pomba é o símbolo tradicional da luz divina e da eternidade. Símbolos de uma era gloriosa e passada, os obeliscos eram entendidos, desde Sixtus V, como símbolos do triunfo do Cristianismo sobre o Paganismo - interpretação essa que vai de encontro com a representação dos quatro continentes do monumento berniniano, uma vez que este reflete a dominação do homem sobre a Terra e, consequentemente, a dominação cristã sobre as outras religiões.

Durante o Império Romano, os obeliscos egípcios eram trazidos em meio a longas caravanas que passavam pelo centro de Roma a fim de exibir espetacularmente o espólio de guerra. Tirados de antigos templos egípcios, os obeliscos exerciam a função de troféus, símbolos da vitória de Roma sobre o poder faraônico, que submeteu a grande civilização egípcia à condição de província do Império. Outros obeliscos, no entanto, foram construídos pelos próprios imperadores romanos, como no caso do Obelisco Pamphilio, para serem colocados nos templos dedicados ao culto dos deuses egípcios em Roma?.

Nesse contexto, a pirâmide simbolizava o poder divino, de onde todas as coisas provinham. A base da pirâmide representava tudo que é criado através do poder divino, cada um dos quatro vértices da base aludia a um elemento: ar, fogo, terra e água, todos provenientes do ápice da

\footnotetext{
${ }^{8}$ FINDLEN, Op. cit., p. 54.

${ }^{9}$ WILDUNG, Dietrich. O Egipto: da pré-história aos romanos. Lisboa: Taschen, 1998, pp. 225 - 226.
} 
pirâmide, que por sua vez representava Deus ${ }^{10}$. O obelisco, cuja forma é composta de uma pirâmide mais o tronco de uma pirâmide, representaria então a ligação entre o intelecto divino, o mundo angelical e a esfera dos elementos ${ }^{11}$. A própria forma do triângulo constituía uma representação importante, pois simbolizava a tríade divina egípcia Osíris, Ísis e Hórus que ele identificava à Santíssima Trindade.

No entanto, é possível ainda associar um significado egipsante ao monumento. Cada um dos animais escolhidos para a fonte possui referência à mitologia egípcia. Por exemplo, o cavalo e o leão possuem uma simbologia complementar um ao outro. O leão simboliza a força solar e a cheia do Nilo, que ocorria quando o Sol atingia o signo de Leão (entre os meses de julho e agosto), trazendo fecundidade ao vale do rio.

Em oposição à divindade solar, que Kircher atribuía a Osíris (e não a Hórus), está Seth, o "vento árido do deserto", deus do deserto e do caos, que mata seu irmão Osíris. No mito, Seth mandou que atirassem o corpo de Osíris no Nilo. Ísis o encontra, mas ao deixar o corpo sozinho, Seth o vê e corta-o em muitos pedaços, espalhando-os pelo Egito. Ísis sai a procura das partes de seu marido e com elas faz a primeira múmia. Contudo, um peixe havia comido os genitais do deus. Ela então os reconstitui magicamente e consegue assim conceber um filho seu, Hórus. Este herda o poder real do pai na terra, enquanto Osíris, para sempre o rei morto, governou o reino dos mortos.

O animal que se associa a Seth é o hipopótamo, também conhecido como "cavalo do rio". Bernini coloca na posição diametralmente oposta a do Leão, um cavalo com a crina agitada pelo vento e emergindo da água. Ambos representando assim o dualismo morte - regeneração, que Kircher acreditava estar presente em todas as religiões antigas ${ }^{12}$.

Desta forma é que Kircher pretendia demonstrar a sua teoria humanística de uma continuidade ideal entre a antiga sabedoria mágica do Egito hermético e a verdade revelada do cristianismo. A importância da obra de Kircher não está no entanto, em seu valor histórico mas na construção de sua argumentação que sua obra é uma das matrizes e um dos pontos de referência do imaginário barroco.

${ }^{10}$ CIPRIANI, Giovanni. Gli obelischi egiz̨: politica e cultura nella Roma Barocca. Florença: Leo S. Olschki Editore, 1993. pp. $124-125$.

${ }^{11}$ RIVOSECCHI. Op. cit., p. 64.

12 RIVOSECCHI. Op. cit., p. 130. 
Essa referência constante a um Egito mítico e idealizado se dava pela necessidade de reconstruir a imagem de uma sabedoria originária, que permitisse traçar uma ligação entre o pontificado de Inocêncio X e seus antecessores, além de identificar no Egito a raiz primária da mensagem do Cristianismo. As próprias diferentes interpretações a que o monumento se propõe se encaixam perfeitamente no pensamento humanista: o monumento é em si mesmo um jogo de conhecimento ${ }^{13}$, permitindo múltiplas interpretações num universo científico-religioso.

${ }^{13}$ FINDLEN, Paula. Jokes of Nature and Joies of knowledge: the playfulness of scientific discourses in early modern europe. 